UDC: $94(477.5) " 1618 / 1648 "$

\author{
Petro Kulakovskyi, \\ Doctor of Historical Sciences (Dr. Hab. in History), \\ Professor of the Regional Studies Department \\ of the National University of Ostroh Academy (Ukraine, Ostroh), \\ kulakovsky@ukr.net, \\ orcid.org/0000-0001-6310-717X
}

\title{
THE GENTRY OF THE GRAND DUCHY OF LITHUANIA ON THE CHERNIHIV-SIVERSKY LANDS (1618-1648)
}

Reconquered during the wars at the beginning of the XVII century, Chernihiv-Siversky lands joined the Polish-Lithuanian Commonwealth being devastated and lacking the holistic social structure. Warsaw faced an ambitious task of colonizing the acquired territories. Considering the essence of the Polish-Lithuanian Commonwealth, the key issue that needed to be resolved was the involvement of the gentry in it. Not only were they supposed to be the promoters of the colonial ideology, but they also had to ensure the creation of the effective system of the regional border defence. Thus, the third goal Warsaw aspired to achieve was quite logical - to reward those who participated in the wars with the Muscovite state by giving them the formerly acquired ChernihivSiversky lands. The Polish-Lithuanian Commonwealth did not have enough human resources, as there was an excess of the landless and land poor gentry. However, it was spread unevenly throughout the country. The high rates were typical for Masovia. The minor gentry of the Volyn and Kyiv Polissia also hoped to improve their material status. The third centre to supply the ChernihivSiversky lands with human resources comprised the palatinates of the Grand Duchy of Lithuania, which were characterized by a lack of land funds and excess of people from the social strata that was transitional between the peasantry and the nobility, namely the boyars and small gentry. The nobility of the Duchy, which was actively arriving at the vicinities of Chernihiv and Novgorod-Siversky in the period from the conclusion of the Truce of Deulino (1618) to the outbreak of the Smolensk War (1632), can be divided into four groups. The first group was represented by the captains from the times of the Moscow Expeditions, well known and relatively wealthy representatives of the Lithuanian-Belarusian nobility. They joined (or tried to join) the local economic elite of the Chernihiv-Siversky lands. They were allocated more land, 
given the potential colonization resource. The regional representatives of this group were the families of Pats, Tryzna, and Polubinski. However, only Patsies managed to achieve the set goal. The second group was represented by Chernihiv and Novgorod-Seversky zemstvo officers. They have earned their titles by building long military careers, backed by personal connections to central government (Marshals) or even members of the ruling royal family. If the titles were of the functional nature (chamberian, judge, deputy judge, or notary), the officer needed to possess the corresponding juridical or clerical experience. Among them were those who carried out their activity on the territories adjacent to the Chernihiv-Siversky region (E. Stravinskyi, D. Kerlo) and those who were rooted directly there (S. Ohnytskyi, S. Minvid). The third group of migrants was made up of members of military units led by the influential regional politicians (S. Pats, O. Pisochynskyi, and others). They had the task of developing a basic defence system for the Chernihiv-Siversky lands. Such people were considerably fewer here than in the neighbouring Smolensk palatinate. As a result, the Smolensk War (1632-1634) revealed some of the system's most fundamental flaws, which the government tried to eliminate after the war was over. This group was sometimes represented by entire military fraternities (Haraburdas). Finally, the fourth group of migrants was comprised of clients, servants, and tenants of the local magnate families. They arrived in the region alongside their patrons and later joined their households (in particular, their economic, military, and clerical units). Their careers were almost completely connected to the Chernihiv-Siversky lands. The representatives of this group constituted the majority of those who stayed in the region after it came under Cossack control.

Keywords: migration, gentry, Chernihiv-Siversky lands, feudal estate law, privilege, Muscovite Expedition.

Петро Кулаковський, доктор історичних наук, професор кафедри країнознавства Національного університету «Острозька академія»

(Україна, Острог), kulakovsky@ukr.net, orcid.org/0000-0001-6310-717X

\section{ШЛЯХТА ВЕЛИКОГО КНЯЗІВСТВА ЛИТОВСЬКОГО НА ЧЕРНІГОВО-СІВЕРЩИНІ (1618-1648 pp.)}

Відвойована в ході війн початку XVII cm. Чернігово-Сіверщина увійшла до складу Польсько-Литовської держави спустошеною і позбавленою більш-менш цілісної соціальної структури. Перед Варшавою постало масштабне завдання колонізації набутих територій. 3 огляду на сутність Речі Посполитої, ключовим питанням, яке належало вирішити, стало залучення туди представників шляхетського стану. Вони мали бути не лише провідниками колонізаційних цілей, але й гарантами створення ефективної системи прикордонної регіональної оборони. Третя ціль, яку намагалися досягти у Варшаві, формулювалася абсолютно 
логічно - винагородити учасників війн з Московською державою за рахунок здобутих земель Чернігово-Сіверщини. Людського ресурсу в Польсько-Литовській державі вистачало - в країні спостерігався надлишок мало- і безземельної шляхти. Однак по території країни вона концентрувалася нерівномірно. Високі показники бути притаманні для Мазовії. Сподівалася на покращення свого майнового стану численна дрібна шляхта Волинського й Київського Полісся. Третім центром постачання кадрів на Чернігово-Сіверщину стали воєводства Великого князівства Литовського, для яких був характерний брак земельного фонду й надлишок перехідних верств між селянством і знаттю, зокрема бояр, та дрібнопомісної шляхти. Нобілітет Князівства, який особливо активно прибував в околиці Чернігова й Новгорода-Сіверського у проміжку від укладення Деулінського перемир'я (1618) до початку Смоленської війни (1632), можна поділити на чотири групи. Першу групу представляли ротмістри часів московських експедицій, добре відомі й відносно заможні представники литовсько-білоруського нобілітету. На Чернігово-Сіверщині вони увійшли (або спробували увійти) до економічної еліти. Земельні надання для них вирізнялися значним масштабом, зважаючи на потенційний колонізаційний ресурс. Ця група в регіоні представлена родами Паців, Тризн, Полубінських. 3 них лише Пацам вдалося виконати поставлене завдання. Друга група представлена чернігівськими й новгород-сіверськими земськими урядниками. Свої уряди вони заслужили впродовж тривалої військової кар'єри, підкріпленої особистими зв'язками з центральними урядниками (гетьманами) чи навіть членами правлячої королівської родини. Якщо ж уряди були функціональними (підкоморій, суддя, підсудок, писар), у гру входила відповідна юридична й діловодна підготовка. Серед них слід виділити тих, хто основну свою діяльність провадив поблизу, але не на Чернігово-Сіверщині (Е. Стравінський, Д. Керло), і тих, хто вкоренився на місцевому грунті (С. Огницький, С. Мінвід). Третю групу мігрантів склали товариші військових підрозділів, очолюваних впливовими регіональними політиками (С. Пац, О. Пісочинський та ін.). Їх завданням стало формування базової системи оборони ЧерніговоСіверщини. Таких людей тут виявилося значно менше, ніж у сусідньому Смоленському воєводстві. Як наслідок, під час Смоленської війни (16321634) виявилися корінні вади цієї системи, які спробували ліквідувати вже після ї̈ завершення. Ця група часами представлена цілими родинними вояцькими братствами (Гарабурди). Зрештою, четверта група мігрантів формувалася з числа клієнтів, слуг, орендарів місцевих магнатських родин. Вони прибули в регіон разом зі своїми патронами, увійшли до складу їх дворів (господарської, військової та діловодно-юридичної складових). Їх кар'єра була майже цілком пов'язана з ЧерніговоСіверщиною. Серед них виявилося найбільше людей, що залишилися в регіоні після його переходу під козацький контроль.

Ключові слова: міграція, шляхта, Чернігово-Сіверщина, ленне право, привілей, московська експедиція. 
The end of 1618 saw the conclusion of the Truce of Deulino, which ended yet one more period of the military confrontation between the Polish-Lithuanian Commonwealth and the Muscovite state. It resulted in the return of the Smolensk lands and a part of Siversky lands to the Polish-Lithuanian Commonwealth. The Smolensk land and the Starodub party of Siversky lands joined the Grand Duchy of Lithuania, while General Diet decided to pass the Chernihiv-Siversky lands to the personal administration of Prince Wladyslaw Waza, who had actively participated in the last years of war against the Muscovite state. The situation in these regions was slightly different. Chernihiv-Siversky lands suffered more demographic losses than the neighbouring Starodub party of Siversky lands and the Smolensk land, which were joined into the Smolensk palatinate. The process of depopulation was especially noticeable among the privileged class. While in the Smolensk palatinate there were still many Muscovite boyars and the boyar children who swore allegiance to Wladyslaw as the Muscovite Prince, on the Chernihiv-Siversky lands their numbers were considerably smaller, and in the first years after the Truce of Deulino only a few of them remained there. Therefore, Wladyslaw Waza and his administrative apparatus faced the problem of attracting human resources to the land. There were only a few conditions for those from the gentry state - to have the experience of participation in the military campaigns against the Muscovite state and to fulfil the duties of defending the region, stipulated by the feudal estate law.

The thirty-year history of the formation of the local gentry corporation allows us to draw a preliminary conclusion that the gentry from three main regions of the then Polish-Lithuanian Commonwealth took part in this process, namely that from: the Crown, Ukrainian palatinates (Volyn, Bratslav, and Kyiv palatinate), and the Grand Duchy of Lithuania. Each of the three groups had their reasons to move to the Chernihiv-Siversky lands. The Crown war represented mostly by the natives of the Masovian palatinate. One of the biggest palatinates of the Polish Crown showed a large percentage of the poor and often landless gentry. The colonization could give them an opportunity to rapidly enhance their property status. The Volyn and Dnipro nobility paid particular interest to the acquired region, seeing it as something akin to "reconquista" - the return of one of the parts of the former Rus state under the sphere of their control. The nobility of the Duchy of Lithuania saw emigration to the Chernihiv-Siversky lands as their ultimate goal. The natural and geographical conditions of the region were largely similar to those of Belarusian Polissia, which facilitated the process of the Duchy`s nobility adaptation to the new territories. There existed one more significant argument that for some time created additional motivation for the LithuanianBelarussian nobility in their intentions to move to Chernihiv and NovgorodSiversky. In the first years after the Truce of Deulino, the political elite of the Grand Duchy of Lithuania had plans to include the Smolensk lands, the Starobub party of Siversky lands, and the Chernihiv-Siversky lands to the Duchy. It was 
these plans that determined the higher rates of the Lithuanian-Belarussian gentry immigration to the region at the beginning of the 1620s. There was one defined condition for the members of all three groups - they had to be participants of the military campaigns of the first two decades of the XVII century, which could give them a right to lay claim to the feudal lands in the Chernihiv-Siversky region.

The research is based on the data regarding the royal privileges for property and governing positions on the territory of the Chernihiv-Siversky lands. They were mainly preserved in the form of official copies in the books of royal chancery, known as the "Crown Metrica". These books were kept by the chancery staff and contained copies of the most significant documents, issued in the monarch`s name. The privileges typically covered the information on the individual's former military achievements, as well as the property and positions granted to them. A part of these privileges was kept in the books of the Ruthenian (Volhynian) Metrica, which is a separate series of books created by the chancery for the purposes of storing information regarding the Ukrainian palatinates of the Polish-Lithuanian Commonwealth (Volyn, Kyiv, Bratslav, and Chernihiv palatinates). Since the Siversky lands joined the Commonwealth together with Smolensk ones, and some of the gentry from the Grand Duchy of Lithuania gained property in both regions, the books of Lithuanian Metrica, which is a series of record books, managed by the royal chancery, provided additional information in the study of the issue. Castle and earthly books of Chernihiv and Novgorod-Siversky did not survive until today, and the loss of the data from them could be only partially compensated by the books` excerpts, issued on personal requests.

The problems of similar contents have never been raised in historiography before. The issue of the gentry`s eastward migration is discussed in the works of Aleksandr Yablonovskyi (Źródła dziejowe, 1897) and Henryk Litwin (Litwin, 2000; Litwin, 2016) but they focused on other Ukrainian palatinates, namely Kyiv and Bratslav ones. The part that the arrived gentry played in the colonization of the Chernihiv-Siversky lands was first investigated by the author of this article (Kulakovskyi, 2006). The stories of the separate immigrants from the Duchy to the region can be found in the works on genealogy and social history, in particular in the monography of Nataliia Yakovenko (Yakovenko, 2008).

The process of the gentry's migration to the Chernihiv-Siversky lands encompassed two stages. The first one started after the conclusion of the Truce of Deulino; the second came into being as an aftereffect of the Smolensk War (16321634), victorious for the Polish-Lithuanian Commonwealth. In 1635, the General Diet of the Polish-Lithuanian Commonwealth decided on the creation of the separate Chernihiv palatinate as a part of the Crown on the territory of the region. This resulted in the extension of the Volhnynian law and Ruthenian language as the language of office to the Chernihiv-Siversky lands. Thus, the process of establishing contacts between the newly formed palatinate and the neighbouring Ukrainian palatinates began. The quantitative ratio of the three already mentio- 
ned regions of the Polish-Lithuanian Commonwealth in the migration flows during these stages differs. While at the first stage, the predominant part of the gentry was arriving from the Grand Duchy of Lithuania, at the second stage their numbers dwindled considerably; instead, the share of the Crown with its Ukrainian palatinates (in particular the Volhynian one) significantly increased. The reason behind it cannot be explained only by the absence of the prospects of joining the Chernihiv-Siversky lands with the Duchy. A far bigger role was played by the fact of the increase in the number of the captains from the Crown and Ukrainian palatinates that actively participated in the Smolensk War. These were the captains and the honoured soldiers from their units who received a large percentage of the land allocations in the region from Wladyslaw IV.

Thus, all Lithuanian-Belarussian gentry that came to the Chernihiv-Siversky lands can be divided into 4 strata. The separation criterion was the role that the arrived took on at the new territories.

The first stratum consists of the economic elite of the Chernihiv palatinate. Its members were normally the captains who distinguished themselves during the wars between the Polish-Lithuanian Commonwealth and the Muscovite state.

Among the large landowners (the feudal estate law implied ownership, not proprietorship) of the Lithuanian-Belorussian origin, we should mention Samuil Pats who received about 400 lans of the Chernihiv-Siversky lands, while the average size of the feudal allocation comprised only several dozens of lans. Samuil belonged to the third most influential family of the Grand Duchy of Lithuania, after the Radzivills and the Sapihs. His brother Stefan held the office of the Lithuanian treasurer, and later of the Vice-chancellor. Unlike Stefan, who devoted his life to a political career, Samuil served in the army from an early age. Under the rule of Marshal Jan Karol Chodkiewicz, Samuil fought in the Livonian War at the beginning of the XVII century. In the course of the Muscovite Expedition in 1610 Pats suffered two injuries. As a captain, he participated in the PolishOttoman War (1621) and the Livonian expedition, which started at the end of 1626. In 1623, the distinguished soldier got the office of the Great Lithuanian Colourbearer. Samuil died in 1627, not having turned 40. He had hereditary possessions in the Brest palatinate, as well as the possessions in the Rechytsk and Mozyrsk districts of the Minsk palatinate (tenancy) and Smolensk palatinate (fief). The Colourbeared had four underage children from his marriage to Petronella Tryznianka, a daughter of the Babruysk prefect and Parnava voivode Petro Tryzna - Jan-Samuil, Dominik-Kazymyr, Anna and Ilaria (Wolff, 1885: 89-92).

The family estate of S. Pats and his sons covered the headstreams of three rivers - Oster, Uday, and Romen. At the centre of this complex stood the town if Ivanhorod, characteristic by its castle fortifications. However, Pats's main landholdings were located in the Polissia part of the region, on the banks of the Snov River. One of the biggest manors of the Chernihiv palatinate was formed here the Sedniv manor (Kulakovskyi, 2006: 261, 267). The manor`s peculiar location 
(Desna River hindered the migration flows from the Ukrainian palatinates, while the way for the similar flows from Belarus stayed open) facilitated the process of its colonization by the immigrants from the Grand Duchy of Lithuania, especially from the Pats's lands. The centre of this manor, Sedniv, had the status of a small town at the turn of the 1630-1640s; it was also at that time when the handicraft guilds started to appear there. During the Cossack revolution, Jan-Samuil participated in the fighting, and Dominik-Kazymyr was taken prisoner by the Muskovite troops. Neither of the Pats's sons had children, so there was no one to lay claim to their feudal lens in the Chernihiv-Siversky region.

A famous Lithuanian family of Tryznas also had a chance to join the economic elite of the Chernihiv palatinate until the mid - 1630s. They had some quite significant reasons for it. The gentry family was once settled in Briansk on the Siversky lands and moved to the Novgorod palatinate only after their native town was captured by the Muscovite troops. Additionally, numerous members of the family participated in the Muscovite expeditions at the beginning of the XVII century. Tryznas' Siversky land's origins gave them a special status in the region. Among everything else, they were returned the property they once owned. Thus, while the biggest part of the properties in the Siversky region was granted by the feudal estate law, Tryznas got their lands through the inheritance law. The bulk of these lands was situated in the Starodub district of the Smolensk palatinate. Some settlements, though, lied in the Siversky district. This way, the settlements and hillforts of Baturyn and Krasne belonged to the Starodub prefect Pavlo Tryzna (Krawczuk, 1999: 85). In 1631, the prefect gave these lands up to his cousin, the Parnava voivoda Petro Tryzna. He owned the settlements of Polonka, Zanka, and Andriievychi in the Volkovysk district (Rejestry popisowe, 2015: 117). The voivoda died in 1633 and his property was inherited by his son - the Bobruysk perfect Petro-Kazymyr. He possessed some military experience of participation in the Polish-Ottoman War in 1621. The Baturyn region had enough resources to allow Petro-Kazymyr to join the ranks of the largest landowners of the region. However, for some unknown reasons, the Bobruysk perfect did not want it and passed Baturyn and Krasne to the royal Vice-chancellor Jerzy Ossolinsky in March 1635 (Krawczuk, 1999: 75). It also changed the legal status of the lands: they became feudal instead of inherited.

There was one more person who also had a chance to join the lists of the landowners on the Chernihiv-Siversky lands - a representative of the princely race of Polubinskyis, the Parnava voivoda Kostiantyn, the son the Lida chamberian Oleksandr and Anna Alemanivna. After graduating from the Brunsberg Jesuit College and the Vilna Academy, he devoted his youth to the military career. He served under Marshal Ja.-K. Chodkiewicz in Livonia, participated in the Muscovite expedition of 1609-1610 and defended the Podilia region under Field Marshal Stanisław Zółkiewski. Later on, Kostiantyn focused mainly on his political career he ran a dietine and the Lithuanian tribunal and was frequently chosen to be an 
ambassador at the Diets. His marriage to the representative of a powerful Lithuanian family of Sapihs, Sofia Sapizhanka, facilitated his promotions. Finally, in 1633 Prince Wladyslaw IV gave Kostiantyn the office of the Parnava voivoda (Lulewicz, 1983: 368-369).

The voivoda`s main properties were located in different districts of the Grand Duchy of Lithuania (Slonim, Lida, Rechytsia, and Orshansk). In January 1634, staying in his camp on the Dnipro River, Prince Wladyslaw granted K. Polubinskyi with two feudal settlements in the Novgorod-Siversky district - Baklan and Kuriv. However, in March of the next year, the Parnava voivoda gave these properties away to the Rechytsia castle judge Oleksandr Bykovskyi (AGAD, Metryka koronna, sygn. 180, k. 267 v.-268; sygn. 181, k. 104 v.-105).

The second stratum was represented by the earthly officials of the ChernihivSiversky lands, and later of the Chernihiv palatinate. There were about ten of them altogether, but we will discuss only three representatives.

In 1623, the native of the Trotsk palatinate Erasm Stravinskyi became the Chernihiv and Novgorod-Siversky chamberian. He held the office of an equerry in his native palatinate (1603-1625). E. Stravinskyi was a distinguished military officer. He fought in the final period of the Livonian War under the rule of Stefan Batory (РГАДА, ф. 389, оп. 1, ед. хр. 197, л. 44). He served as a royal captain in 1609 and took part in various military campaigns as well as the Muscovite expeditions in 1600-1611. During one of such expeditions, Erasm was captured by the Muscovites and imprisoned in Nizhny Novgorod from 1612 through 1619. He made his first attempt to joins the ranks of the Ukrainian palatinates`gentry at the end of the 1580s. For a few years (1588-1590) he served as Kyiv castle notary. In 1589, Erasm received a royal privilege for three uninhabited settlements: Yuriivshchyna on the Stuhna River, Mylovshchyna, and Ivankiv, which lies on the left bank of the Dnipro River. Possessing a required privilege, he tried to take the position of the Kyiv vogt in 1593. However, both the common people and the gentry did not take his initiative well and E. Stravinskyi did not manage to retain the power he received (Bilous, 2008: 105, 106). Things went easier with the Chernihiv-Siversky lands, where there were no gentry corporations as of 1618 . Moreover, the person who recommended Erasm for the office and lobbied his interests was none other than Prince Wladyslaw Waza. Backed by his support, E. Stravinskyi received seven settlements and half of the woodlands in the Chernihiv-Siversky region even before he became the chamberian. Nevertheless, judging from his next legal steps, Erasm did not plan to stay in the region, so he sold all of his properties to his kin in 1625. Stravinskyi was married to Shostovska Raina Dmytrivna and they had three daughters: Khrystyna, Helena, and Yana. Erasm also gave some of his lands (in Zhadiv and Slot) to his cousin Adam's sons, Bartholomew and Bazylii (РГАДА, ф. 389, оп. 1, ед. хр. 209, л. 330 об.-331 об.). They did not stay in the region for long, though; there are no records of them being members of the local gentry corporation. 
Another chamberian (up to March of 1635 - of two districts, from March through November - of a single Novgorod-Siversky district), Dadzhyboh Kerlo also came from the Grand Duchy of Lithuania. He was not exactly a native of the Duchy, for in 1623, as a foreigner who contributed to the welfare of the PolishLithuanian Commonwealth, he received a confirmation of the Polish gentry indigenat (Materiały, 1995: 62). However, based on his place of residence and family relation (he was married to Khrystyna Volovychivna), Kerlo was undoubtedly closer to the Lithuanian gentry. Dadzhyboh actively participated in the military expeditions of 1600-1618 and was among the most trusted servants of Prince Wladyslaw Waza, having worked his way up to the position of the general steward at his court. He directly owned only a single settlement on the ChernihivSiversky lands - the village of Seniavyne (Krawczuk, 1999: 28). Based on the data from the 1638 Register of yards, in which Seniavyne is listed as the property of Petronella Tryznianka, the village was given to Tryznas after D. Kerlo died. The chamberian and his family had firmer positions in the Starobub party of Siversky lands. For instance, he obtained one of the largest centres of this subregion, Pochep, through the feudal estate law (РГАДА, ф. 389, оп. 1, ед. хр. 99, л. 610 об.611). His son Gabriel is recorded as the Pochep leaseholder and the Starodub chairman.

Stefan Ognytsykyi, an active participant of the Muscovite expeditions of 16091618, also immigrated to the region from the Grand Duchy of Lithuania. These were his military achievements that earned him the ennoblement from the Lithuania Marshal Jan-Karol Chodkiewicz in 1616. The Marshal himself died shortly after he was wounded in the battle of Khotyn, so Ognytsykyi`s further fate was in the hands of Prince Wladyslaw. The latter gave Ognytsykyi three settlements in the Smolensk palatinate in 1623 (Lukianov, Shchukla, and Krukovo) (РГАДА, ф. 389, оп. 1, ед. хр. 99, л. 534-534 об.). Stefan, apart from his military prowess, was well-skilled in law and clerical work. This earned him the position of Novgorod-Siversky earthly deputy judge in March of 1623 (AGAD, Metryka koronna, sygn. 170, k. 161-161 v.). In June 1628, Stefan became the NovgorodSiversky earthly judge and held the position until February 1637. He owned three settlements on the Chernihiv-Siversky lands, namely Lenkove, Yesman, and a part of Studenka (AGAD, Metryka koronna, sygn. 191, k. 262-262 v.). His son Andrzej gave his part of Studenka away but kept his other properties up until the beginning of the Cossack revolution.

Another gentry representative, Stanislav Minvid, came from the Calvinist family in the Trotsk palatinate and served as a Novgorod-Siversky supdapifer during 1623-1646 (Urzędnicy, 2002: 239). Unlike his relatives, who pursued the clerical career, Stanislav served in the army when he was young. He went through the Livonian War at the beginning of the XVII century and the battles for the Polish-Lithuanian Commonwealth`s eastward expansion, including the Siege of Smolensk in 1609-1611. Because of Minvid`s religious affiliation, the Field 
Marshal, and later the Great Lithuanian Marshal Krzysztof Radziwill acted as his protector. Minvid received the settlements of Podoliv and Sopych in 1620 and was nominated for the position of supdapifer in 1623 (РГАДА, ф. 389, оп. 1, ед. хр. 209, л. 176-177 об.). When the Novgorod-Siversky perfect Oleksandr Pisochynskyi came to the region and proved himself to be a skilled politician, Minvid joined his camp. Shortly before 1638, Stanislav gifted the prefect with the village of Sopych, and was even recorded to be the prefect's deputy capitaneus on the Novgorod-Siversky lands in the 1640s.

The third stratum comprised the representatives of the average gentry who earned one or several settlements in the region with their former military achievements. The Haraburda family, whose ancestral home was located on the Polotsk land, had an especially vibrant presence in the region. Most of them were building their military careers (at least partially) in the military unit of the aforementioned S. Pats.

It is not certain whether it was this military unit where Haraburda Marko Vasyliovych served during the Muscovite campaign, after which he received the settlement of Borshchiv not far from Novgorod-Siversky in 1624 (РГАДА, ф. 389, оп. 1, ед. хр. 209, л. 221 об.-223). Instead, it was documented that his two sons, Jan and Gabriel, served exactly in the Pats`s unit. Jan had many years of army service behind him. Among his various experiences we should mention his participation in the long-lasting Siege of Smolensk (1609-1611), the Muscovite expedition of Prince Wladyslaw, and one of the Livonian campaigns. Not only did he serve under S. Pats, but he also joined the unit of the Smolensk voivoda Oleksandr Korvin-Gonsevskyi. When Muscovite troops conquered NovgorodSiversky in the winter of 1632, Jan was taken prisoner. He returned home in 1634 and, according to the records, spent at least ten more years on the ChernihivSiversky lands. Jan inherited several settlements from his father (Deshkovychi, Lukyne, Borshchiv) and made or tried to make transactions with them. He was married to Sofi Miliadovska. Another Marko's son, Gabriel, fought under S. Pats as well. He became a landlord on the Chernihiv-Siversky lands after his brother Jan let him have the village of Lukyne in 1629 (AGAD, Metryka koronna, sygn. 177, k. 390-391). Gabriel lived and did his military service in Novgorod-Siversky. Just like his brother, he was captured by the Muscovites after the city was taken and was supposed to be imprisoned in Rylsk. There are no records of his further fate whatsoever.

Haraburda Oleksandr Janovych and Haraburda Olbrykht Janovych also belonged to the gentry corporation of the region. Oleksander was a soldier in the unit of the Smolensk castellan Baltazar Stravinskyi. He participated in the Livonian campaign in 1629. The same year, his brother and he received the settlements of Deshkovychi and Horodyshche in the Chernihiv-Siversky region after they were relinquished by Haraburda Jan Markovych (AGAD, Metryka koronna, sygn. 181, k. 81-82). Both brothers also were captured by the Muscovites after the latter had 
taken the city. In 1636, Oleksandr reallocated his share of Deshkovychi and Horodyshche in the behalf of Jan Kunynskyi and Eva Stravinska. Olbrykht, apart from doing service in the military unit of B. Stravinskyi, is also recorded as a comrade the S. Pats's unit. He was well-married to Helena Stravinska, which resulted in E. Stravinskyi giving 0. Haraburda the villages of Chausiv and Vitelm (AGAD, Metryka koronna, sygn. 180, k. 557 v. -558 v.), as well as a number of the uninhabited settlements in the Chernihiv-Siversky region. In all other respects, his fate resembled that of his brother (the imprisonment and the property transaction to J. Kunynskyi and E. Stravinska).

We do not know exactly which was the part of the Haraburdas that Adam represented. Having taken part in the Muscovite expedition, he received the village of Rhoshch near Chernihiv in 1620 through the feudal estate law (РГАДА, ф. 389, оп. 1, ед. хр. 209, л. 196 об.-198).

Finally, the fourth stratum consisted of tenants, lan Cossacks, smallholders of mills and homesteads, their clients, and the magnate families (the latter could be tenants, serve in the court troops, or work at different chancelleries of their patrons). This category of the gentry is the most obscure research-wise, and only a small part of it can be actually calculated. Here are some examples.

Berhelevychs of the "Belt" coat came from the Volkovysk district (Rejestry popisowe, 2015: 122). After a census of the Grand Duchy of Lithuania`s gentry in 1621, brought into being by the general mobilization for the Polish-Ottoman War, Mrs. Berheleva sent her son away "the Cossack way", on a horse. The son`s name was likely Valentii. In December of 1633, as a comrade of a lan Cossacks military unit, he received 12 lans on the desolates Velyka Ves and Mala Ves near Chernihiv. Lan Cossacks were to serve under a prefect and defend the Chernihiv Castle (AGAD, Metryka koronna, sygn. 180, k. 245-245 v.). We suppose that Valentii had a son named Jan. He took the position of a Chernihiv mayor not later than in 1667. Around the same time, Jan takes part in the Chernihiv dietine, which was held in the town of Volodymyr in the Volyn region (Kulecki, 1997: 26-27). The Chernihiv mayor rented the village of Vorona from the Volodymyr authorities.

The Lithuanian gentry also penetrated the Chernihiv-Siversky urban community. In November 1649, Marshal Bohdan Khmelnytskyi approved the decision of Chernihic city community to elect Ivan (Jan) Skynder as a vogt and warden a the city and a whole district. The sources say that he owned the Kuvychytsia mill at that time (Universaly, 1998: 93-94). Skynders of the coats of "Shreniava" and "Ravych" can be found in various regions of the Grand Duchy of Lithuania, namely in its Lida district of the Vilen palatinate, Trotsk palatinate, and the Duchy of Samogotia. The 1621 gentry census of these territories contains the records on Jan and Petro Skynder, who owned Khoroshkovshchyna in Volkovysk district, and Stanislav Skynder, who rented the village of Lopennyky in the said district (Rejestry popisowe, 2015: 67, 68, 126, 127). Ivan Skynder came to Chernihiv 
through the Lubetsk eldership that has always been known as a major centre of the small gentry.

Samuil Volodkovych likely originated from Zhmud (Rejestry popisowe, 2015: $56,57)$. Having proved to be a skilled soldier during the Muscovite expedition (1616-1618), he obtained 20 feudal lans on the banks of the Divytsia River in 1624. Due to the unknown reasons, he relinquished the Divytsia lands to Stanislaw Pianchynskyi in 1627, who later became Chernihiv deputy judge and judge. S. Volodkovych, in his turn, received a part of the settlement Nekrasove in Siversky district from Oleksandr Lypskyi (AGAD, Metryka koronna, sygn. 173, k. 472-474). The exchange was clearly unequal, as Divytsia was located in one of the most profitable and productive parts of the Chernihiv-Siversky lands, which cannot be said of Nekrasove. This might have been the reason why Samuil tried to stay near Divytsia. At the end of the same year, he was announced as one of the gentry members who were included in the unit of the lan defense that stayed nearby Nizhyn. Possessing this privilege, S. Volodkevych obtained 8 lans on the Divytsia and Losynohlovy lands (AGAD, Metryka koronna, sygn. 176, k. 116-116 v.). The sources vicariously state that Samuil acted as the first settler in the part of Divytsia owned by Adam Kysil, and started a farm on the banks of Pivdenka River near Divytsia.

When the Chernihiv-Siversky lands joined the Polish-Lithuanian Commonwealth, the region had virtually no political elite. The majority of Muscovite boyars and their children left the territories; only a small number of them swore allegiance to the Polish-Lithuanian Prince. Warsaw faced the task of building a solid gentry corporation here. It was directly connected to the problem of organizing the defence for the integrated region. The royal court believed that the reliable defence capability could be ensured by the introduction of the feudal estate law, which entailed the defined military responsibilities for the local landowners. This approach limited the magnate families' access to the colonization of the Chernihiv-Siversky lands, and cleared the way for the land-poor and middle-class gentry instead, together with those who participated in the Muscovite expeditions at the beginning of XVII century. We can define three major regions that "supplied" the gentry to the vicinities of Chernihiv and NovgorodSiversky: Masovian palatinate of the Crown and the Ukrainian palatinates, among which Volyn palatinate and the Grand Duchy of Lithuania. Newcomers from the Duchy played an important part in the formation of the gentry corporation of the Chernihiv palatinate. There are two periods that can be clearly distinguished in the process of their migration: 1) from 1618 to 1632 (the beginning of the Smolensk War) and 2) from 1634 (the end of this War) to 1648 (the beginning of the Cossack revolution). It was during the first adjustment period when the status of the Chernihiv-Siversky lands had not yet been decided, that the immigrants from the Grand Duchy of Lithuania were taking an active part in the creation of the local nobility class. They gave rise to the representatives of the magnate 
circles, zemstvo officers, average landowners, and various categories of the vassal gentry. During the second period, due to the creation of the palatinate under the Crown in the region, the number of gentry coming from the Duchy decreased. Overall, the gentry inflow to the Chernihiv-Siversky lands reflected the large-scale immigration processes that took place in the history of the region in the first half of the XVII century.

\section{ARCHIVES}

AGAD - Archiwum Głuwny Akt Dawnych w Warszawie [The Central Archive of Ancient Documents in Warsaw].

РГАДА - Российский государственный архив древних актов [Russian State Archive of Early Acts].

\section{BIBLIOGRAPHY}

Білоус Н. Київ наприкінці XV - першій половині XVII століття. Міська влада i самоврядування. Київ: Видавничий дім "Києво-Могилянська академія", 2008, 360.

Кулаковський П. Чернігово-Сіверщина у складі Речі Посполитої (1618-1648). Київ: Темпора, 2006, 496.

Літвін Г. Шляхта Київщини, Волині та Бращлавщини (1569-1648). Київ: ДУХ і ЛITЕРА., 2016, 616.

Універсали Богдана Хмельницького 1648-1657 / Упоряд. I. Крип'якевич, I. Бутич. Київ: Видавничий дім "Альтернативи", 1998, 383.

Яковенко Н. Українська шляхта з кінця XIV - до середини XVII століття. Волинь і Центральна Україна. Київ: Критика, 2008, 472.

Krawczuk W. Sumariusz metryki koronnej. Księga wpisów kancelarii koronnej podkanclerzego Tomasza Zamoyskiego z lat 1628-1635 ze zbiorów sztokholmskiego Riksarkivet sygnatura Skokloster E[nskilda] 8636. Kraków: Towarystwo Wydawnicze "Historia Jagellonica", 1999, 133.

Kulecki M. Wygnańcy ze Wschodu. Egzulanci w Rzeczypospolitej w ostatnich latach panowania Jana Kazimierza i za panowania Michała Korybuta Wiśniowieckiego. Warszawa: DIG, 1997, 237.

Litwin H. Napływ szlachty polskiej na Ukrainę 1569-1648. Warszawa: Semper, 2000, 224.

Lulewicz H. Połubiński Konstanty h. własnego. Polski Słownik Biograficzny. Wrocław; Warszawa; Kraków; Gdańsk; Łódź: Wydawnictwo PAN, 1983, т. XXVII, 368-369.

Materiały genealogiczne, nobilitacie, indygenaty $w$ zbiorach Archiwum Głównego Akt Dawnych w Warszawie / Oprac. A. Wajs. Warszawa: DIG, 1995, 136. 
Rejestry popisowe pospolitego ruszenia szlachty Wielkiego księstwa Litewskiego z 1621 roku / Oprac. Andrzej Rachuba. Warszawa: DIG, 2015, 174.

Urzędnicy województw kijowskiego i czernihowskiego XV-XVIII wieku. Spisy / Oprac. E. Janas, W. Kłaczewski. Kórnik: Poznańska drukarnia naukowa, 2002, 344.

Wolff J. Pacowie. Materiały historyczno-genealogiczne. Petrsburg: z drukarni F. Suszczyńskiego, 1885, 375.

Źródła dziejowe. Warszawa: skł. gł. w księg. Gebethnera i Wolffa, 1897, т. XXII: Ziemie Ruskie. Ukraina (Kijów-Bracław) / Wyd. Aleksander Jabłonowski, 736+LX.

\section{REFERENCES}

Bilous, 2008 - Bilous, N. (2008). Kyiv naprykintsi XV - pershiy polovyni XVII stolittia. Mis'ka vlada i samovriaduvannia. Kyiv: Vydavnychyi dim "KyievoMohylians'ka akademija". [in Ukrainian].

Krawczuk, 1999 - Krawczuk, W. (Comps.). (1999). Sumariusz metryki koronnej. Księga wpisów kancelarii koronnej podkanclerzego Tomasza Zamoyskiego z lat 1628-1635 ze zbiorów sztokholmskiego Riksarkivet sygnatura Skokloster E[nskilda] 8636. Kraków: Towarystwo Wydawnicze "Historia Jagellonica". [in Polish].

Kulakovskyi, 2006 - Kulakovskyi, P. (2006). Chernihovo-Sivershchyna u skladi Rechi Pospolytoi (1618-1648). Kyiv: Tempora. [in Ukrainian].

Kulecki, 1997 - Kulecki, M. (1997). Wygnańcy ze Wschodu. Egzulanci w Rzeczypospolitej $w$ ostatnich latach panowania Jana Kazimierza $i$ za panowania Michała Korybuta Wiśniowieckiego. Warszawa: DIG. [in Polish].

Litwin, 2000 - Litwin H. (2000). Napływ szlachty polskiej na Ukrainę 1569-1648. Warszawa: Semper. [in Polish].

Litwin, 2016 - Litwin, H. (2016). Shliakhta Kyivshchyny, Volyni ta Bratslavshchyny (1569-1648). Kyiv: Dukh i litera. [in Ukrainian].

Lulewicz, 1983 - Lulewicz H. (1983). Połubiński Konstanty h. własnego. Polski Słownik Biograficzny (Vol. XXVII). Wrocław; Warszawa; Kraków; Gdańsk; Łódź: Wydawnictwo PAN. 368-369. [in Polish].

Materiały, 1995 - Wajs, A. (Comps.). (1995). Materiały genealogiczne, nobilitacie, indygenaty $w$ zbiorach Archiwum Głównego Akt Dawnych $w$ Warszawie. Warszawa: DIG. [in Polish].

Rejestry popisowe, 2015 - Rachuba, A. (Comps.). (2015). Rejestry popisowe pospolitego ruszenia szlachty Wielkiego księstwa Litewskiego z 1621 roku. Warszawa: DIG. [in Polish].

Universaly, 1998 - Krypiakevych, I., \& Butych I. (Comps.). (1998). Universaly Bohdana Khmel'nyts'koho, 1648-1657. Kyiv: Vydavnychyi dim "Al'ternatyvy". [in Ukrainian]. 
Urzędnicy, 2002 - Janas, E., \& Kłaczewski, W. (Comps.). (2002). Urzędnicy województw kijowskiego i czernihowskiego XV-XVIII wieku. Spisy. Kórnik: Poznańska drukarnia naukowa. [in Polish].

Wolff, 1885 - Wolff, J. (1885). Pacowie. Materiały historyczno-genealogiczne. Petrsburg: z drukarni F. Suszczyńskiego. [in Polish].

Yakovenko, 2008 - Yakovenko, N. (2008). Ukrains'ka shliakhta z kintsia XIV - do seredyny XVII stolittia: Volyn' ta Tsentral'na Ukraina. Kyiv: Krytyka. [in Ukrainian].

Źródła dziejowe -Jabłonowski, A. (Comps.). (1897). Źródła dziejowe. (Vol. XXII: Ziemie Ruskie. Ukraina (Kijów-Bracław)). Warszawa: skł. gł. w księg. Gebethnera i Wolffa. [in Polish]. 